\title{
Hubungan Integritas Guru PAK Dalam Melaksanakan Tugas dan Tanggungjawab Terhadap Motivasi Belajar Siswa
}

\author{
Andrianus Nababan ${ }^{1)}$, Warseto Freddy Sihombing ${ }^{2)}$ \\ ${ }^{1}$ Prodi PAK, Institut Agama Kristen Negeri Tarutung \\ ${ }^{2}$ Prodi Teologi, Institut Agama Kristen Negeri Tarutung
}

\begin{abstract}
This study aims to determine relationship and magnitude of christian religious teacher's integrity in carrying out their duties and responsibilities on Students Learning Motivation SMP Negeri 2 Lintongnihuta. The number of samples here were 129 students. Data was collected by means of a questionnaire using descriptive analysis. The results showed that there was an effect of christian religious teacher integrity in carrying out duties and responsibilities With Students Learning Motivation. This research were analyzed using descriptive and inferential statistical data analysis techniques with the following steps: (1) The relationship test found that rcount> rtable was $0.621>0.349$. It can be concluded that there is a positive relationship between the Integrity of hristian religious Teachers with Duties and Responsibilities, (2) The significant test of the relationship shows that tcount> ttable is 4.338> 2.042. Based on the results of this study, teachers of religious education must have integrity that greatly influences a person in carrying out their duties and responsibilities regularly, consistently, honestly, in accordance with professional ethics code for christian religious teachers. As result, student interest and motivation will increase.

Keywords:christian education teacher, integrity, duties, responsibilities, motivation
\end{abstract}

\begin{abstract}
Abstrak
Penelitian ini bertujuan untuk mengetahui sejauh mana integritas guru PAK dalam melaksanakan tugas dan tanggungjawab terhadap motivasi belajar siswa kepada siswa SMP Negeri 2 Lintongnihuta. Jumlah sampel dalam penelitian ini sebanyak 129 siswa. Pengumpulan data dilakukan dengan kuesioner dengan menggunakan analisis deskriptif. Hasil penelitian menunjukkan bahwa ada hubungan integritas guru PAK dalam melaksanakan tugas dan tanggungjawab terhadap motivasi belajar siswa. Data penelitian dianalisis dengan menggunakan teknik analisis data statistik deskriptif dan inferensial dengan langkah sebagai berikut: (1) Uji hubungan diketahui bahwa $r_{\text {hitung }}>r_{\text {tabel }}$ sebesar $0.621>0.349$. Dapat disimpulkan bahwa terdapat hubungan yang positif antara Integritas Guru PAK dalam Tugas dan Tanggungjawab terhadap motivasi belajar siswa , (2) Uji signifikan hubungan diketahui bahwa $t_{\text {hitung }}>t_{\text {tabel }}$ sebesar $4.338>2.042$. Berdasarkan hasil penelitian ini, Guru pendidikan agama kristen harus memiliki integritas karena sangat berhubungan seseorang dalam melaksanakan tugas dan tanggungjawabnya dengan teratur, konsisten, jujur dan sesuai dengan kode etik profesional guru PAK. Dampaknya, motivasi siswa semakin meningkat.
\end{abstract}

Katakunci : guru PAK, integritas, tugas, tanggungjawab, motivasi

116 Korespondensi mengenai artikel dapat dilakukan kepada:

Andrianus Nababan, IAKN Tarutung, Jl. Raya Tarutung-Siborong KM 11, Silangkitang, Sipoholon, Tapanuli Utara (22452), Indonesia

Email: andri.nababan1992@gmail.com 


\section{PENDAHULUAN}

Integritas yang dimiliki seorang guru PAK (Pendidikan Agama Kristen) menjadikannya seorang pribadi yang utuh, sempurna, memiliki ketulusan hati, tak bernoda secara moral, serta dapat menjadi teladan karena adanya konsistensi antara perkataan dan perbuatan yang menolong kita untuk mencapai tujuan yang paling penting. Setiap guru agama kristen memang harus memiliki integritas karena hal ini penting dalam menunjukkan perbedaan dengan guru-guru lainnya dan karena dalam pengajarannya, seorang guru Kristen memiliki ciri khas tersendiri dalam mengajar: sesuai dengan perintah yang telah diamanatkan oleh Tuhan Yesus kepada muridmuridnya. Hal ini bertujuan untuk meningkatkan motivasi belajar siswa dalam belajar segala sesuatu mengenai Tuhan dan ciptaan-Nya di dalam kelas.

Motivasi adalah suatu kondisi dalam tubuh manusia yang dapat dilukiskan sebagai keinginan, dorongan dan apa saja yang menggerakan seseorang berperilaku tertentu untuk memenuhi keinginan atau dorongan. Motivasi dapat ditinjau dari dua sifat, yaitu motivasi intrinsik dan motivasi ekstrinsik Wirawan, (2013:176). Motivasi intrinsik adalah keinginan bertindak yang disebabkan pendorong dari dalam individu, sedangkan motivasi ekstrinsik adalah motivasi yang keberadaannya karena pengaruh dari luar individu. Tingkah laku yang terjadi pada diri seorang siswa dapat dipengaruhi oleh lingkungan, orang tua, kawan sebaya dan guru.

Sehingga kurangnya pemahaman guru agama kristen terhadap siswa dalam tugas dan tanggungjawab bisa mengakibatkan siswa kurang termotivasi dalam belajar (pendidikan) agama kristen. L. Eims mengungkapkan bahwa seorang pemimpin harus berminat untuk memotivasi pada dua arah ke dalam dan ke luar (Eims, (2000:52). Secara ke dalam mereka harus diberi motivasi untuk mengadakan persekutuan dengan Yesus Kristus sebagai Guru Agung. Seorang guru PAK yang mempunyai integritas baik pasti akan memiliki motivasi belajar di dalam melaksanakan tugas dan tanggung jawabnya sebagai pengajar. Dengan demikian terdapat hubungan antara integritas seorang guru PAK dalam melaksanakan tugas dan tanggung jawab terhadap motivasi belajar siswa yang diembannya sebagai pengajar. Integritas yang dimiliki akan mendorong seorang guru agama kristen dalam memanajemen waktu dan rencana pembelajaran untuk menghasilkan pendidikan yang mengubahkan peserta didik.

117 | Hubungan Integritas Guru PAK dalam Melaksanakan Tugas dan Tanggungjawab ..., Andrianus, Warseto Jurnal Christian Humanioran | http://e-journal.iakntarutung.ac.id/index.php/humaniora 


\section{METODE PENELITIAN}

Metode yang digunakan dalam penelitian ini adalah metode kuantitatif deskriptif dan inferensial. Data angka tersebut berasal dari pengukuran yang menggunakan skala terhadap variable yang ada dalam penelitian ini. Lokasi Penelitian ini adalah di SMP Negeri 2 Lintongnihuta kabupaten Humbanghasundutan. Populasi dalam penelitian ini ada sebanyak 645 siswa. Sampel merupakan wakil dari populasi yang akan diteliti dan penentuan sampel dilakukan menggunakan metode random sampling dengan tingkat representatif sebesar 20\%. Sehingga sampel pada penelitian ini adalah berjumlah 129 orang. Data dari sampel tersebut dikumpulkan dengan menggunakan angket (questionare). Instrumen yang digunakan dalam penelitian ini terlebih dahulu telah diujicoba terhadap 30 orang responden di sekolah lain. Yang dianggap representatif dengan responden penelitian, Dan seluruh instrument valid, reliabel, dan layak digunakan sebagai instrument dalam penelitian ini. Untuk menguji apakah koefisien regresi signifikan atau tidak, maka akan dihitung dengan membandingkan uji t hitung dengan $\mathrm{t}_{\text {tabel. }}$ dengan menggunakan rumus sebagai berikut:

$$
t=\frac{b-\beta_{0}}{S_{Y . X} / \sqrt{S_{X X}}}
$$

\section{PEMBAHASAN DAN HASIL}

\section{Firman Allah Sebagai Dasar}

Kebenaran firman Allah adalah dasar dari pengajaran guru agama kristen, sebagaimana pendapat Lumban Gaol \& Nababan, (2019) bahwa guru PAK seyogianya memberikan pengajaran kepada siswa tentang kebenaran Firman Tuhan yang bersumber dari Alkitab. Adanya integritas menjadikan seorang guru menjadi seorang pribadi yang tidak hanya mentransferkan ilmu kepada siswa-siswanya tetapi juga mentransferkan nilai-nilai dan prinsip hidup yang berdasarkan Kristus. Tindakan seorang guru Kristen yang selalu menunjukkan integritas akan menjadi kebiasaan dan kebiasaan tersebut akan menjadi karakter dan akhirnya akan menjadi gaya hidup kristiani. Pengembangan integritas dapat dilakukan dalam kehidupan sehari-hari meskipun dalam pekara kecil tanpa dibatasi dengan waktu dan tempat.

Menurut Belandina, (2009:26) "integritas adalah konsistensi antara kata dengan perbuatan yang menjadi teladan bagi peserta didik. Carter (1999:10) berpendapat bahwa 
integritas adalah: "pribadi yang utuh yang entah bagaimana tak terpecah-pecah". Menurut Kamus Webster's New World yang dikutip oleh Simanjuntak, 2008:49) mengatakan "integritas adalah mutu atau sifat yang utuh, keadaan tidak terpecah, tidak terpisah-pisah, sempurna, tidak rusak, sehat dan tak bernoda secara moral, benar dan jujur".

Guru harus selalu mengajarkan apa yang dia miliki secara pribadi sehingga dapat memproyeksikan kehidupannya kepada murid-muridnya, sehingga apa yang baik atau buruk yang diajarkan kepada murid-murid, itulah cerminan dirinya. Sejalan dari pendapat Nababan, (2020) bahwa guru PAK adalah seseorang yang rela mengabdikan dirinya untuk mendidik, membentuk pribadi siswa, dan yang membimbing serta mengarahkan peserta didik untuk menanamkan nilai-nilai moral kristiani. Jadi, guru PAK harus memberikan pengajaran mengenai cara hidup yang baik maka siswa pun akan mengikutinya begitu pun sebaliknya. Seorang guru kristen harus menunjukkan integritasnya sebagai guru kristen baik yang sesuai dengan pikiran, perbuatan, dan kelakukan seseorang yang berdasarkan Alkitab. Keseharian hidup seorang guru kristen harus menunjukkan gaya hidupnya yang berintegritas sekalipun orang lain tidak tahu. Sesungguhnya saat dimana orang tidak mengetahui pikiran, perasaan dan perbuatannya pada saat itulah level integritasnya diuji.

\section{Pentingnya Integritas Guru Agama Kristen}

Hal yang terpenting dari integritas ialah memiliki keutuhan dalam mengajar sesuai dengan perintah Tuhan Yesus serta mengajar dengan segenap hati untuk menolong setiap murid. Integritas harus berdasarkan pengajaran Tuhan Yesus karena hal itu yang sangat membantu dalam keberhasilan siswa yang diajar dan yang membedakan dengan guru-guru lainnya karena sebagai guru Kristen wajib membangun anak yang berkarakter dan berkualitas berdasarkan firman. Dimana menurut Nababan, (2020) bahwa guru PAK yang harus mampu melaksanakan tugas di bidang PAK dengan mengandalkan kemampuan dan karakter yang tinggi dan mengacu pada sosok Yesus sebagai Guru Agung. Pada intinya memiliki integritas bagi seorang guru kristen merupakan hal yang sangat penting dalam melaksanakan tugas dan tanggung jawab sebagai pengajar.

119 | Hubungan Integritas Guru PAK dalam Melaksanakan Tugas dan Tanggungjawab ..., Andrianus, Warseto Jurnal Christian Humanioran | http://e-journal.iakntarutung.ac.id/index.php/humaniora 
Dalam pengajaran, hal yang sering membuat guru merasa kehilangan integritas yaitu saat guru diperhadapkan dengan mata pelajaran pendidikan agama kristen yang sama luasnya dengan kehidupan kita, dan juga diperhadapkan dengan siswa yang mungkin membuat seorang guru menjadi bingung dan terjebak dalam pengajaran di kelas. Sering para guru kristen juga tidak menyadari hal ini, guru berasumsi bahwa hal itu merupakan hal yang tidak menjadi masalah padahal inilah sebenarnya merupakan masalah yang besar jika para guru tidak memiliki integritas dalam mengajar.

Setiap guru Kristen seharusnya memiliki integritas yang baik di dalam kelas terhadap siswanya dalam mengajar, dan integritas tersebut dapat dilihat dari cara pengajarannya serta teknik-teknik yang mereka kuasai dalam penanganan kelas. Bagaimana mereka mengajar di kelas, seperti contoh ketika mendidik siswa yang memiliki kelakukan yang tidak baik; apakah guru akan mudah emosi dalam menasihati siswa yang melanggar aturan dan yang lainnya. Atau, apakah dia sebagai seorang guru kristen berintegritas akan membimbing siswa tersebut ke arah yang lebih baik dengan kasih dan kesabaran dari Tuhan.

Tugas guru tidak hanya sebatas mengajar, melainkan juga sebagai seorang pembimbing dan motivator siswa dalam hal karakter. Seorang guru perlu memahami tugasnya agar dapat berfungsi dengan baik. Menurut Sidjabat, (2011:100) yang menjadi tugas seorang guru PAK adalah: "sebagai pendidik (educator), pengajar (instructor), pembimbing (guide), pengarah (director), pelatih (trainer), penilai (evaluator), pemberita injil (evangelist), imam (priest), gembala (pastor), konselor (counselor) dan telog (theologian)”. Menurut Homrighousen, (2009:165) :“Tugas guru dalam PAK sangat penting dan tanggung jawabnya sangat berat. Guru dipanggil untuk membagikan harta abadi dalam tugasnya. Ia memegang keberadaan Injil Ilahi, dimana dalam pekerjaannya sebagai pengajar, ia sedang menghadapi jiwa manusia yang besar nilainya dihadapan Allah". Menurut Hendricks yang dikutip oleh Sidjabat, (2011:103) mengusulkan ada tiga tugas guru PAK yaitu:1) teach people how to think, 2) teach people how to learn, 3) teach people how to work maksudnya, guru terpanggil untuk mengajari muridnya bagaimana berpikir, bagaimana cara yang tepat belajar dan bekerja, sebab dngan cara-cara itulah mereka akan belajar. Sedangkan menurut 
Nainggolan Jhon M, (2010:57) mengatakan bahwa "tugas guru PAK adalah menjembatani antara pendidikan iman dengan persoalan hidup sehari-hari dimana guru PAK harus bisa merelevansikan antara berita Alkitab dengan kehidupan sehari-hari peserta didik".

Integritas adalah kesesuaian antara ucapan seseorang dengan tindakannya dimana integritas itu merupakan bagian dari kepribadian yang mampu membedakan seorang guru biasa dengan guru PAK. Seorang Guru PAK yang memiliki integritas akan terlihat dari sikapnya yang mencakup: mampu bekerja secara teratur dan konsisten, bertindak sesuai dengan norma hukum, memiliki rasa bangga sebagai pendidik, bertindak sesuai dengan norma sosial, memiliki tanggungjawab, kesetiaan, serta kejujuran.

\section{Tugas dan Tanggung Jawab Guru Agama Kristen}

Dasar Alkitab bagi seorang guru agama kristen unutuk menjalankan tugas dan tanggungjawabnya dalam penelitian ini didasarkan pada teks Alkitab 2 Timotius 3:16, "Segala tulisan yang diilhamkan Allah memang bermanfaat untuk mengajar, untuk menyatakan kesalahan, untuk memperbaiki kelakuan dan untuk mendidik orang dalam kebenaran." Teks ini memang menjelaskan tugas utama Timotius dalam penggembalaan yang dipercayakan kepadanya. Paulus, dalam hal ini bertindak sebagai rasul dan gembala memberikan dasar yang teguh kepada Timotius berkenaan dengan tugas dan tanggung jawabnya dalam pelayanan kepada jemaat. Guthrie, (2013:235) berpendapat bahwa Paulus mendorong Timotius sebagai seorang pengajar untuk teguh berdiri dan diingatkan akan nilai Kitab Suci yang tidak tergantikan. Sebagai seorang yang memiliki pengalaman banyak dalam pelayanan dan sebagai orang tua rohani, Paulus menasihati Timotius sebagai anak rohaninya untuk dapat menjadi seorang pelayan Tuhan yang berintegritas.

Dalam teks tersebut, terkandung makna tugas dan tanggungjawab seorang pengajar kekristenan/agama. Terdapat empat (4) kata kerja penting dalam teks ini: mengajar, menyatakan, memperbaiki, mendidik yang kesemuanya berkaitan dengan mengetahui dan mengalami kebenaran Allah. Kata kerja mengajar adalah penekanan khusus dalam surat-surat penggembalaan yang menjadi tugas utama seorang gembala/pelayan di jemaat. Menyatakan kesalahan dapat diartikan "menginsafkan" 
dalam teks ini, dimana kesalahan jemaat tidak boleh dibiarkan, agar tidak berkembang menjadi kesalahan yang lebih besar pada waktu ke depannya. Kata kerja memperbaiki kelakuan dapat menunjuk kepada evaluasi dan peningkatan seorang percaya di waktu yang selanjutnya. Dan mendidik orang dalam kebenaran dapat diartikan dengan kepada latihan atau pembinaan dalam iman orang percaya. Timotius memiliki tugas dan tanggung jawab sebagai gembala jemaat di Efesus yang sudah dipercayakan Paulus kepadanya. Alkitab (Firman Allah) adalah sarana yang digunakan oleh Roh Kudus untuk pertumbuhan rohani orang percaya-tegas Paulus.

Berdasarkan penjelasan di atas, tugas dan tanggung jawab pada bagian itu juga dapat diterapkan pada pelaksanaan pengajaran seorang guru agama kristen. Seorang guru kristen dapat bertugas sebagai pembimbing, gembala, konselor, penilai, pengarah, dan seorang teolog bagi siswa di kelas. Integritas seorang guru kristen akan tampak nyata ketika ia menyadari panggilannya sebagai pengajar dapat mengimplikasikan pesan Allah dalam 2 Timotius 3:16 tersebut. Para guru kristen akan mau mengajar, membimbing, memotivasi dan mempengaruhi para siswa menjadi siswa yang semangat dan memiliki keinginan belajar yang tinggi. Guru kristen yang melaksankan tugas dan tanggungjawabnya dengan teratur, konsisten, jujur, sesuai dengan aturan yang berlaku pasti akan memperoleh hasil yang baik — siswa yang termotivasi dalam belajar. Jadi, tindakan dalam mengajar, menyatakan kesalahan, memperbaiki kelakuan dan mendidik orang dalam kebenaran Allah (dalam hal ini adalah peserta didik di sekolah) merupakan bagian dari integritas guru kristen. Dan pada faktanya integritas guru PAK ini memiliki pengaruh terhadap motivasi belajar siswa.

\section{Hasil}

Berdasarkan hasil penelitian melalui data yang diperoleh dari responden orang, maka pembahasan hasil penelitian sebagai berikut: Berdasarkan uji persyaratan analisis untuk menguji apakah terdapat hubungan antara variabel integritas guru PAK dalam melaksanakan tugas dan tanggungjawab terhadap motivasi belajar siswa. Dengan

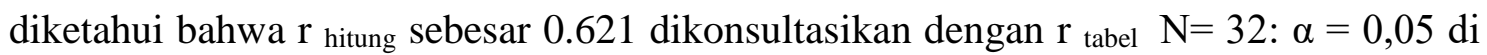
dapat sebesar 0.349 . Jadi $r_{\text {hitung }}>r_{\text {tabel }}(0.621>0.349)$ artinya terdapat hubungan yang positif antara integritas guru PAK dalam melaksanakan tugas dan tanggungjawab 
dengan motivasi belajar siswa. Melalui uji $\mathrm{t}$ diketahui bahwa thitung 4.338 dikonsultasikan dengan tabel $(n-2)=(32-2)=30$ untuk $\alpha / 2=0,05 / 2=0,025$ sebesar $=$ 2.042 jadi $t_{\text {hitung }}>\mathrm{t}_{\text {tabel }}(4.338>2.042)$. Artinya terdapat hubungan yang signifikan antara integritas guru PAK dalam melaksanakan tugas dan tanggungjawab terhadap motivasi belajar siswa.

Jika diamati besar koefisien kedua variabel penelitian ini dapat variabel $\mathrm{X}$ dengan Y memiliki korelasi sedang. Hasil analisis yang diperoleh memberikan gambaran bahwa ternyata integritas guru PAK dalam melaksanakan tugas dan tanggungjawab terhadap motivasi belajar siswa ialah korelasi sebesar 1,393. Sehingga hasil Pengujian hipotesis menunjukan bahwa hubungan yang signifikan dan positif baik pada integritas guru PAK dalam melaksanakan tugas dan tanggungjawab dengan motivasi belajar siswa. Hal ini berarti semua hipotesis baik dan hipotesis yang dikemukakan dalam penelitian ini dapat diterima.

\section{KESIMPULAN}

Seorang guru PAK harus memiliki integritas dalam melaksanakan tugas dan tanggungjawab terhadap motivasi belajar siswa. Dengan memiliki integritas maka mampu bekerja secara teratur dan konsisten, bertindak sesuai dengan kode etik guru, belajar dari kesalahan, memperbaiki kelakuan, mendidik orang dalam kebenaran sehingga motivasi belajar siswa tertarik dan memiliki gairah untuk menerima materi pelajaran yang hendak disampaikan dan mampu mengembangkan kemampuan mengajar dan mengembangkan pedagogik dalam proses pembelajaran.

\section{UCAPAN TERIMAKASIH}

Terima kasih kepada Tuhan Yesus yang senantiasa memberikan hikmat kepada penulis dan kepada Kepala Sekolah, guru pendidikan agama kristen dan siswa yang terlibat membantu dalam penelitian jurnal ini. Terima kasih juga kepada tim Jurnal Christian Humaniora Tarutung. Semoga tulisan ini dapat bermanfaat dan menjadi berkat bagi setiap orang yang membacanya. 


\section{DAFTAR PUSTAKA}

Arikunto. (2002). Metodologi Penelitian Suatu Pendekatan Proposal. Jakarta: PT. Rineka Cipta.

Belandina, J. (2009). Profesionalisme Guru dan Bingkai Materi. Bandung: Bina Media Informasi.

Eims, L. (2000). Pemuridan Seni yang Hilang. Bandung: Lembaga Literatur Babtis.

Guthrie. (2013). Pengatar Perjanjian Baru Volume 2. Jakarta: BPK Gunung Mulia.

Homrighousen, E. . dan E. (2009). Pendidikan Agama Kristen. Jakarta: BPK Gunung Mulia.

Lumban Gaol, N. T., \& Nababan, A. (2019). Kepemimpinan Guru Pendidikan Agama Kristen. Kelola: Jurnal Manajemen Pendidikan, 6(1), 89-96. https://doi.org/10.24246/j.jk.2019.v6.i1.p89-96

Nababan, A. (2020a). Enhancing The Character of Students Through The Implementation of 2013 Curriculum at SMK Negeri 1 Siatas Barita. 2006.

Nababan, A. (2020b). Pemahaman Guru Pendidikan Agama Kristen tentang Mempersembahkan Tubuh Roma 12 : 1-3. 4(1), 1-12.

Nainggolan Jhon M. (2010). Guru Agama Kristen Sebagai Panggilan dan Profesi. Bandung: Bina Media Informasi.

Sidjabat, B. S. (2000). Menjadi Guru Profesional Sebuah Persepektif Kristiani. Jabar: IKAPIR.

Simanjuntak. (2008). Integritas Seorang Hamba. Tarutung: Kantor Pusat HKBP Pearaja.

Sugiyono. (2013). Metode Penelitian Kuantitatif, Kualitatif dan R\&D. Bandung: Alfabeta.CV.

Wirawan. (2013). Kepemimpinan. Jakarta: Rajawali Pers. 